Benjamine TOUSSAINT

\title{
Location and dis-location in George Douglas Brown's The House with the Green Shutters
}

Perhaps because Scotland is placed geographically and linguistically at the periphery of the United Kingdom by an Anglo-centric vision, Scottish writers often write from and about particular places. This paper focuses on the way the notions of place and space structure George Douglas Brown's The House with the Green Shutters (1901). First the role of place in defining the identities of individuals is analysed, because "place and self are thoroughly enmeshed" (Casey 2001a, 684). The paper then focuses on the maps of power and spatial dynamics that shape the geography of the novel. This reveals the complexity of a work that simultaneously endorses and deconstructs a polarized vision of space in terms of centre and periphery. Finally, topographical metaphors appear as a means to unite the local and the universal when the main character's hubris and downfall are expressed through images of verticality that also characterize the local landscape.

Le Royaume-Uni est souvent envisagé d'un point de vue anglo-centrique qui relègue l'Écosse à la marge du pays, tant d'un point de vue géographique que linguistique. Pour cette raison sans doute, la notion de lieu occupe une place prépondérante dans la littérature écossaise. Cet article se penche donc sur la façon dont cette notion de lieu - et la notion corrélative d'espace - structurent le roman de George Douglas Brown, The House with the Green Shutters (1901). Dans un premier temps l'analyse porte sur la manière dont le lieu façonne l'identité des personnages car, selon Casey, lieu et identité sont intimement et profondément liés (Casey 2001a, 684). La démonstration s'intéresse ensuite à la cartographie du pouvoir que dessine le roman. Celle-ci révèle la complexité d'un texte qui alterne entre acceptation et déconstruction $d u$ dualisme centre-périphérie, conduisant ainsi le lecteur à modifier son propre positionnement. Enfin, les métaphores spatiales se révèlent être un moyen pour le romancier de lier le local et l'universel, puisque l'hubris du personnage principal et sa chute sont exprimées à travers des images qui font écho à la topographie écossaise.

Paint village hell where sadist monster mutters

Till Scotland's one mad House with the Green Shutters;

Depict the lust that lurks in hall and hovel,

And build thereon a Scottish national novel.

(Quoted by Macdonald, 164) 
The notion of locality was a key element in late nineteenth-century Scottish popular fiction and in how it was perceived by contemporary criticism. On 19 January 1895, The Times stated that "few things are more remarkable in the recent history of our literature, than the rise of a new school of Scottish fiction, drawing its inspiration from locality and national character" (Nash 319, my emphasis). The influence of these sentimentalised tales of rural Scotland was all the more forceful since "they were eagerly devoured outside Scotland" (Nash 319). However, not all contemporaries reacted as favourably as The Times. The success of such tales and the distorted, utopian vision of Scotland they created, irritated Scottish critics like J.H. Millar, R.B. Cunninghame Graham or J.H. Findlater, who worried that "a partial, unrepresentative view of Scottish life was being marketed to an international audience" and who lamented "the predominance of rural settings, the parochial outlook, the nostalgic tone, the exaggerated pathos, the excessive emphasis on religion, the cosmetic use of dialect and the obvious concession to audience demand" (Nash 319). Millar described the works of James Barrie, S.R. Crockett and Ian Maclaren as "the Great Kailyard Movement" (Nash 317). Kailyard is a Scottish word meaning “cabbage patch," and Millar's phrase highlights the rural and domestic aspects that are typical of the genre while also suggesting its slightness. Although recent criticism is calling for a revision of this critical perception and for a more nuanced approach that would acknowledge the greater quality of Crockett's and Barrie's works (Nash; Carruthers 118), the derogatory phrase coined by Millar has remained.

A turning point occurred in 1901 when George Douglas Brown published The House with the Green Shutters and "stuck the Kailyarders like pigs" (Sommers 252). The titles of some Kailyard works-such as Barrie's A Window in Thrums (1890) or Maclaren's Beside the Bonnie Brier Bush (1894)-hint at the importance of the sense of place and belonging. Moreover, the label "Kailyard fiction" itself suggests a narrowly constricted space which is both generic and yet linguistically inscribed within Scotland. With his title, Brown "takes to the satiric extreme the idea of the diminutive perspective of the Kailyard mentality: the title focuses not simply on a parish, not simply on one house, but on a closefocus detail of a house" (Carruthers 119). It is striking that, despite this insistence on locality, notions such as place and space should have been relatively little used in critical analyses of The House with the Green Shutters. Criticism usually focuses on the Kailyard and anti-Kailyard elements, although other literary influences are also underlined, ${ }^{1}$ espe-

1. Most critics deal with the Kailyard issue at some point in their analysis and it is central in articles such as "George Douglas Brown's Kailyard Novel” or "The House with the Green Shutters and the Seeing Eye." A reference to other influences, especially Scottish, English, French and classical literature, can be found in Craig's introduction, in the $25^{\text {th }}$ chapter of Scottish Literature (Gifford 2002) or in the third volume of The 
cially those of Greek tragedy, on account of Brown's classical training at Glasgow University and Balliol College, Oxford. The portrayal of the socio-economic evolution of rural Scotland and its impact on the local population is also underlined in all the general presentations of the work, as well as in Christian Civardi's analysis. However, only in Bernard Sellin's articles do we find a critical analysis focusing more particularly on the importance of "the organization of space" (Sellin 1992, 173).

As Sellin underlines, the title itself is our first clue to the crucial significance of the notion of place in the novel, giving prominence to the dwelling rather than to its inhabitants. The main protagonist, John Gourlay, is a proud and powerful carrier who terrorises the inhabitants of Barbie-a "petty burgh [...] scarce bigger than a village" in Ayrshire (33) - as well as his own family. His prosperity begins to decline when James Wilson returns to Barbie after a fifteen-year absence to start his own business. The conflict between the two men takes not only the shape of commercial competition but also that of a rivalry by proxy through the education they provide for their sons. Gourlay being ruined by the arrival of the railway, his only hope for the future of his family resides in his neurotic son. The latter, however, will murder his father before committing suicide. As we shall see, the eponymous "House with the Green Shutters" plays a key role in the plot as well as in the symbolism of the novel. In The Poetics of Space (1957), the French philosopher Gaston Bachelard argues that "[a] house constitutes a body of images that give mankind proofs or illusions of stability" (38), and one of Gourlay's fatal flaws will be to mistake his house for a stable symbol of power even while he is progressively losing his grasp on it by using it as security to borrow money.

Place and space are a complex conceptual pair, for "[c]ulturally and socially, there is a continual movement between place and space as nondichotomously related and ever-shifting terms" (Casey 2001b, 720). For Casey, place has the power to "direct and stabilize us, to memorialize and identify us, to tell us who and what we are in terms of where we are" (Casey 1993, xv, original emphasis). This paper begins with an analysis of place, which is to be understood, for the purposes of this discussion, as location and, more particularly, as home. Several points in this first part of the paper build on Sellin's analysis. However, whilst Sellin uses Bachelard's La Terre et les Rêveries du repos and Olivier Marc's Psychanalyse de la maison as critical frameworks for his analysis, here the focus is on Bachelard's Poetics of Space. The paper then shifts to an examination of the spatial dynamics at work in the novel. Indeed, stories "traverse and organize places; they select and link them together; they

History of Scottish Literature (Gifford 1988) for instance and it is further developed in George Douglas et le roman dramatique (Decap). Articles by Scott or Sommers dwell more specifically on the influence of Stevenson and Hardy, and Royle sees the novel as being haunted by Hamlet's ghost. 
make sentences and itineraries out of them. They are spatial trajectories" (de Certeau 115). This leads to a focus on the itineraries travelled by the characters and the narrator, in order to analyse the way in which the various places they visit are organised and defined in relation to their central place of origin. Maps, however, are often maps of power. Thinking in terms of centre and periphery creates a sense of hierarchy which suggests an interaction between this horizontal axis and a vertical axis of power which determines one's place in society. Since the downfall of the Gourlay family is such a vital part of the plot, the vertical axis that structures the novel will be the focus of the final part of this paper.

\section{"There is no place like home"}

Home refers to a place imbued with a specific meaning, a refuge from external threats. This is so universal a feeling that it is encapsulated in commonplace phrases such as "There is no place like home," which might very well serve as the motto of many a Kailyard novel. It appears in The House with the Green Shutters in the shape of a sampler in the house of the Wilsons:

Out of the flowerpot rose gauntly a three-sticked frame, up which two lonely stalks of a climbing plant tried to scramble, but failed miserably to reach the top. The round little rickety table with the family album on one corner (placed at what Mrs. Wilson considered a beautiful artistic angle to the window), the tawdry cloth, the green mat, the shiny horsehair sofa, and the stuffy atmosphere, were all in perfect harmony of ugliness. A sampler on the wall informed the world that there was no place like home. (98)

The sampler, a potent symbol of domesticity, should theoretically contribute to reinforce the impression of homeliness; however, this expectation is undermined by the sarcastic suggestion that this artefact "inform[s] the world." Besides, the description of the Wilsons' domestic interior suggests the ludicrousness of applying such a statement to their house when we consider the caustic comment about Mrs. Wilson's pseudo-artistic tastes or the oxymoronic association of harmony and ugliness. The atmosphere of the place is not only "stuffy," there is even a suggestion that it is almost lethal, since the plants-the only living presence in this scene-struggle to survive. Indeed the scene described in this passage suggests the antithesis of the notions of cosiness and prettiness one usually associates with home. The narrator's irony is double-edged, being both an individual attack against Mrs. Wilson's poor taste and a debunking of the "home sweet home" myth.

With the above quotation in mind, therefore, we must remain wary of sentimentalising the concept of "home" within the novel. Nonetheless, the notion of location, of belonging to a specific place, is particularly important to the novel. The narrator, after evoking John Jr.'s intense emotional connection with his native town and surrounding countryside, 
enlarges his perspective and argues that the specificity of the Scottish landscape has such an influence on its native people that a deep sense of belonging is actually a defining feature of their national character:

But though he longed to go here and there for a day, that he might be able to boast of it at home, young Gourlay felt that leaving Barbie for good would be a cutting of his heart-strings. Each feature of it, town and landward, was a crony of old years. In a land like Barbie [...], each facet of nature has an individuality so separate and so strong that if you live with it a little it becomes your friend, and a memory so dear that you kiss the thought of it in absence. [...] That is why the heart of the Scot dies in flat southern lands; he lives in a vacancy; at dawn there is no Ben Agray to nod recognition through the mists. And that is why, when he gets north of Carlisle, he shouts with glee as each remembered object sweeps on the sight: yonder's the Nith with a fisherman hip-deep jigging at his rod, and yonder's Corsoncon with the mist on his brow. It is less the totality of the place than the individual feature that pulls at the heart, and it was the individual feature that pulled at young Gourlay. (129-30)

It is important to note that, in this passage, the narrator does not seem to take a critical stance towards Scotsmen's attachment to their native place; on the contrary, it is presented as a fact justified by the specificity (or even "personality," on the ground of the numerous animistic and anthropomorphic elements in the description) of the Scottish landscapes and the suggestion that they are far superior to English ones.

While "home" can refer to one's hometown, even more crucially, it can also refer to one's own house: "For our house is our corner of the world. [...] it is our first universe, a real cosmos in every sense of the word" (Bachelard 26). The private homes in Barbie remain largely unknown to the reader, with two notable exceptions: the Wilson house and the House with the Green Shutters. Little attention is paid to the former, apart from the quick sketch quoted above; it is merely a counterpoint to the latter, as the dwelling of Gourlay's antagonist. The most important aspect of the Wilson house is actually the public space of the shop rather than the smaller private space used as lodgings by the Wilsons (Sellin 1993, 193). The House with the Green Shutters on the other hand is a central presence from both a geographical and a diegetic point of view, because of its localisation in the village and of the space it occupies in the plot.

The novel opens on a description of Barbie, but it is soon revealed that the whole scene has been described from the vantage point of the House with the Green Shutters (2) and the last lines show the "bodies," i.e. the town's dignitaries, staring at the house (252). The House with the Green Shutters embodies the two houses to which is ascribed the highest symbolic importance in Bachelard's Poetics of Space: the childhood house which has conditioned our relation to all our following abodes, and the one we build—or dream of building-for ourselves. To the son, the House with the Green Shutters is a haven, the only place where the terrified boy feels protected from the hostile outside world and sheltered 
from his own father since he can hide in the attic. His own variation on the "home sweet home" topos expresses the sense of safety and delight he experiences as soon as he passes the gate of the House with the Green Shutters: "Oh, Crickey, it's fine to be home!" (44). To his father, on the other hand, it is an assertion of his power in the face of his enemies.

When Gourlay, conscious that he is not sufficiently clever to achieve any civic eminence, invests all his money and ambition in his house, he claims that he prefers "the substantial reality" (14); however, what his attitude reveals is precisely that the symbolic value of his house is much more important than its "real," "substantial" value. The fact that the house was thus built for display suggests an instinctive knowledge of what Bourdieu calls symbolic power. Indeed, both visually and spatially, the building asserts Gourlay's status as the "greatest man" in the parish, even though, ironically, investing so much of his capital in this house eventually leads to his ruin. The house is built "on a little natural terrace that projected a considerable distance into the Square" with walls and railings low enough for the whole house to be "bare to the view from the ground up"; "the dwelling seemed to thrust itself out for notice. It took the eye of a stranger the moment he entered the Square- 'Whose place is that?' was his natural question" (14). Furthermore, its central position is traditionally that of a church or a city hall so that, in a way, it is as if the house enabled Gourlay to achieve a form of civic prominence by proxy.

In the eyes of Gourlay and of all the inhabitants of Barbie, there is a metonymical relationship between the man and his house; not only is the house described as a "worthy counterpart to its owner" (14) but they are actually inseparable and even indistinguishable from each other:

He had a triple wrath to his son. He had not only ruined his own life; he had destroyed his father's hope that by entering the ministry he might restore the Gourlay reputation. Above all, he had disgraced the House with the Green Shutters. That was the crown of his offending. Gourlay felt for the house of his pride even more than for himself-rather the house was himself; there was no division between them. He had built it bluff to represent him to the world. It was his character in stone and lime. He clung to it, as the dull, fierce mind, unable to live in thought, clings to a material source of pride. And John had disgraced it. Even if fortune took a turn for the better, Green Shutters would be laughed at the country over, as the home of a prodigal. (201, my emphasis)

What is striking here is his animistic perception of the house, and the fact that the House of Gourlay matters less to him than the material house he has built, which further demonstrates the all-important symbolic value of the House with the Green Shutters. This form of selfidentification with one's house may seem extreme from a rational point of view, but from a poetic point of view it simply goes towards confirming Bachelard's assertion that " $[\mathrm{o}] \mathrm{n}$ whatever theoretical horizon we examine it, the house image would appear to have become the topography of our intimate being" (Bachelard 20). 
While the narrator debunks the mawkish myths of domesticity, he clearly does acknowledge the visceral attachment men feel towards their homes, and this is what makes this novel particularly bleak, since the house for which the father and son care so much will not be the haven that one usually associates with the notion of home and that John Jr. believes it to be. Not only is it the place where the son will kill his father but, by the time the whole family dies within its walls, it is actually no longer theirs: they have been ruined and the house is sequestered. Moreover, the passion that father and son feel for this house crystallises their hatred for each other. The father considers that his son's failure is a betrayal of the house, and the son hates his father for having sent him away from it. The narrator hints at the influence of Greek tragedy on this novel by describing the "bodies" as "the chorus to Gourlay's tragedy" (80), and here it is as if the CEdipus myth had been rewritten with the house as the mother figure. Indeed, as Bachelard underlines, it is not uncommon for a house to have maternal features, although what we have in this novel is a destructive rather than a nurturing mother figure. The House with the Green Shutters is not only the theatre where tragedy takes place, it is also one of its characters and the tragedy's only survivor.

\section{Giving One's Cubs and One's Readers “a cast o' the world”: Dislocation vs. Decentering}

Claiming that home is the centre of our universe does not imply that our universe should not expand beyond this central point. The opening chapter not only draws our attention to Gourlay's pride in his house as a symbol of his power, but also to his satisfaction at the prospect of sending all his carts at once through the town because this enables him to demonstrate his power through occupation of the town's space. Geographical expansion has long been associated with power, and this explains why "to give their cubs a 'cast o' the world' was a rule with the potentates of Barbie" (128). The scale of the distance that the young boys travel is indicative of their fathers' positions in the social hierarchy of the town, and gives them ascendancy over their schoolfellows. In addition, when the "bodies" choose "the Bend o'the Brae" as their "favourite stance" (26), it is because it is not far from the Red Lion but also because it enables them to survey several streets at the same time. This panoptical vision gives them a knowledge of-and therefore a form of control over-the whereabouts of the inhabitants of the town, which clearly evokes Foucault's theorisation of the relation between knowledge and power. Similarly, Gourlay stresses his authority through deciding to prevent his son from travelling "for the sake of asserting his superiority" (126) or, just as arbitrarily, to displace the boy against the latter's will when he sends him first to high school in Skeighan then to university in Edinburgh "to be upsides with Wilson" (110).

Thus we see how places are not simply locations that can be pinpointed on a geographical map, they also symbolise psychological and social spaces in which struggles take place to appropriate and (re)define 
territories. The final stage of John Jr.'s progressive exile from home is not an actual journey but an imaginary one. The farthest place he visits, albeit indirectly, is not Edinburgh, but Lapland. Although he does not travel there physically, he imagines it in an essay on "An Arctic night." This is the second most important place in the novel after the House with the Green Shutters itself, since winning the Raeburn prize represents a turning point in John Jr.'s life and becomes “one of the many causes working to destroy him" (157). In some ways, the plot of The House with the Green Shutters resembles that of a Bildungsroman and, had the novel conformed to the characteristics of this genre, John Jr.'s real and imaginary journeys would have been instruments and/or symbols of his growing emancipation. His essay might have granted him artistic authority, and the place he appropriates through writing might have endowed him with symbolic power. Indeed, in the British national consciousness and cultural imaginary, the Arctic is constructed as a space that explorers should conquer to demonstrate both their masculinity and the superiority of their nation (Hill). The Arctic and the House with the Green Shutters thus become the two symbolic poles on the horizontal axis of the novel. They are not only geographically distant from each other, they also represent opposed values if one takes into account the ideology of separate spheres that was still dominant in 1901. The House with the Green Shutters represents the domestic space that should be the realm of the feminine, and the Arctic represents the public space to be conquered to display triumphant manhood. Were these two places stable symbols, John Jr.'s trajectory would be a traditional teleological tale of masculine emancipation. However, this potential destiny is thwarted by Gourlay's extreme masculinity and his capacity to destroy it in others, including his own son:

I saw [Gourlay] "down" a man at the Cross once, a big man with a Viking beard, dark brown, from which you would have looked for manliness. Gourlay, with stabbing eyes, threatened, and birred, and "downed" him, till he crept away with a face like chalk, and a hunted, furtive eye. Curiously it was his manly beard that made the look such a pain, for its contrasting colour showed the white face of the coward-and a coward had no right to such a beard. [...] To break a man's spirit so, take that from him which he will never recover while he lives, send him slinking away animo castrato-for that is what it comes to-is a sinister outrage of the world. [...] Yet it was this outrage that Gourlay meant to work upon his son. He would work him down and down, this son of his, till he was less than a man, a frightened, furtive animal. (210-11)

Although the actual origin of the man mentioned above remains unknown to us, his "Viking beard" identifies him with Northern masculinity. ${ }^{2}$ Gourlay's domination over this man-and, symbolically, over the

2. This vision of the masculine North, however, does not apply to the North of Scotland. Indeed there is even a mocking allusion to the "more emotional districts of the North, where it pleases them to shed the tear" (148), but this is due to the fact that the 
North-results in further assertion of his own overpowering masculinity, but it also defuses the possibility of John's own virile conquest of the North. Whilst Gourlay imagines his unmanning of his son as a future action, we are aware that he has already performed this symbolic castration. As a result, when John Jr. imagines the Arctic he cannot envision it as a place of triumphant virility. It is a space of "encircling whiteness" (148), the same colour as the "face of the coward" (210). The only warrior-like figure in this essay is the sea, armed with a metaphorical weapon (148). In this terrifying place a lonely man is "struck dead by the icy water on his brow, which smote the brain like a tomahawk," and he emits a "skirl" (148) as he falls. "Skirl" designates both the sound of a bagpipe and a shrill sound, and the latter definition is hardly suggestive of manliness. As a matter of fact, in the novel, it is always used to refer to female characters, with only two exceptions: the dead man in John Jr.'s essay and the Deacon (40)_but, as Craig emphasizes, "the 'bodies' of the town are constantly represented as gossiping old women" (ix). The character created by John Jr. is not only unmanned, he is dead and " $t]$ he white dead man at the helm" of the ship drifting "on the pathless waters" (ix) foreshadows John Jr.'s own drifting and final destruction. $\mathrm{He}$ may write about the Arctic but he is unable to conquer it, even by proxy.

According to Casey, a strong self is required to overcome the anxiety of displacement. John Jr. is not psychologically equipped to overcome such trauma, a point which is made in very physical terms that reveal how violent an experience his departure for Edinburgh is: "From the earth in which he was rooted so deeply his father tore him, to fling him on a world he had forbidden him to know. His heart presaged disaster" (130). The place in which he feels rooted actually proves as unreliable a gendered symbol as the Arctic. Indeed, Mrs. Gourlay fails to endow the House with the Green Shutters with domestic charms, a fact that both the narrator and Gourlay repeatedly insist on. Whilst the outside of the house, under the rule of Gourlay himself, is neat, the inside of the house is in a permanent state of disorganisation because of his "slattern" wife. Gourlay constantly victimises her, almost to the point of dehumanising her, thus making her unfit to fulfil her supposedly "womanly" role with respect to both her husband and the House with the Green Shutters.

The ideology of the separate spheres is a social construct, and it could therefore certainly be seen as progressive if The House with the Green Shutters intentionally destroyed those gendered identities to present the reader with an alternative, more gender-fluid space. However, the novel clearly endorses the traditional gendered associations of domestic space and conquerable public space. The collapse of gendered identities there-

general opposition between the allegedly feminine South and the allegedly masculine North is counteracted in the case of the North and South of Scotland by another cultural myth according to which the Lowlands are inhabited by manly Anglo-Saxons while the Highlands are the lands of the effeminate Gaels. 
fore simply illustrates the toxic effect of patriarchy embodied in its most extreme form as absolute masculinity and authority. The two places that mark out John Jr.'s trajectory thus appear unstable. He proves unable to own them by properly dwelling in them: his Arctic essay is inhabited by a wandering corpse and he is eventually deprived of the house that should have been his. "The fates of self and place are linked" (Casey $2001 \mathrm{~b}, 717$ ) and what we see in the novel is the destructive effect of mutually impoverishing self and place, a dis-location in space leading to a dislocation of the self.

John Jr.'s failure to broaden his horizons should not be misinterpreted as a vindication of immobility, of a refusal to move beyond one's idealised place of origin. Indeed, the novel offers a less obvious but more successful tale of an outward journey: that of the reader. Barbie may be the centre of the characters' world but it is clearly not that of either the narrator or the implied reader. Brown's work is clearly aimed at a readership beyond the Scottish borders, yet what matters to the present analysis is not whether his actual readers were Scottish or not, but rather that the reader constructed by the text as the narrator's privileged addressee is clearly not Scottish. In this regard, some of the narrative strategies in The House with the Green Shutters are reminiscent of those of the Kailyard novel. Indeed, the exoticism of the Kailyard novel required the presence of a narrator that had evolved beyond the characters' microcosm and yet possessed sufficient intimate knowledge of this place and community to be an efficient interpreter between the implied reader and the Other, embodied by the Scottish rural community. While in the Kailyard novel this narrator is usually a schoolmaster, a doctor or a minister (Campbell and Vogel 92), the identity-professional or otherwise-of the narrator of The House with the Green Shutters remains a mystery. His mastery of Scottish vernacular suggests Scottish origins, but his use of standard English as well as his pseudo-ethnological stance position him as an outsider. When dissecting Scottish cultural specificities or national character for the reader's benefit, he often uses the phrase "the Scot" and the use of the definite article and singular noun rather than the indefinite article followed by a plural suggests not simply generalisation but rather categorization, which is characteristic of scientific discourse. This kind of discourse implies an act of distancing because "the price of becoming a producer of knowledge (and a definer and guardian of things said to be knowledge) involves setting oneself apart from the thing one is studying” (Massey 74).

However, the narrator invalidates his own taxonomic discourse since he sometimes reduces Scottish identity to a single unified national identity through sweeping generalisations whilst, in other passages of the text, he suggests regional differences within Scotland. It becomes even more confusing when, after opposing the different "breeds" of the East and the West of Scotland, he tells us that a single individual can embody both regional characters since Mrs Wilson "could coax you to the buy- 
ing like a Cumnock quean, and fleece you in the selling like the cadgers o'Kincardine" (71). If the regional categories of Scotland are not reliable, why should the national categorisation be any more trustworthy? Indeed, for all his insistence on analysing the characters' behaviours through the prism of their national character, the narrator occasionally acknowledges the universal nature of their feelings and reminds us that "every man is in any man somewhere" (89).

Moreover, in spite of the distance that the narrator seems to maintain most of the time between himself and the other characters, his position sometimes shifts to one of closer proximity and even inclusion within the general Scottish community or the particular community of Barbie when he refers to "our good Scots proverb" (83) or says: "Ours is a nippy locality" (65). Besides, he claims he has read one of young Wilson's letters and witnessed Gourlay's "downing” of the man with the Viking beard. This information is not presented as the kind of knowledge possessed by an extradiegetic omniscient narrator but as that of an insider, of an intradiegetic narrator who has been posturing as an outsider.

Even the reader's own identity and position as an outsider are destabilised at one point in the novel. The narrator's tendency to describe Scottish national features to his implied reader makes it clear that the latter is not Scottish, yet there is one occurrence in the novel when the narrator actually blurs the line. After giving a definition of the "Scotch Cuddy" (75) — which implies that this figure would not be familiar to his reader-and referring to him in the third person, the narrator suddenly switches to the second person pronoun for the rest of the paragraph, thus identifying his reader with the Scotch Cuddy and forging new connections through linguistic tricks:

The "Scotch cuddy" is so called because he is a beast of burden, and not from the nature of his wits. He is a travelling packman, who infests communities of working-men, and disposes of his goods on the credit system, receiving payment in instalments. You go into a working-man's house (when he is away from home for preference), and laying a swatch of cloth across his wife's knee, "What do you think of that, mistress?" you inquire, watching the effect keenly. [...] She has no ready money, and would never have the cheek to go into a draper's and order the suit; but when she sees it lying there across her knee, she just cannot resist it. (And fine you knew that when you clinked it down before her!) (75)

Of course the use of this pronoun could be justified on the ground that it can have a generic meaning, but its repetition and the description of the emotions experienced by this "you" actually involve the reader in the scene.

There is also an interesting paradox in the narrator's comments about the landscapes. While on several occasions he asserts the paramount importance of the influence that their native landscapes exercise on Scottish people, he also repeatedly describes situations in which the characters 
are so self-centred that they are blind to the beauty of the landscape surrounding them. This apparent contradiction enables the narrator to reinforce the bond between himself and his reader and to create a safe place, distant from the malevolent community: the characters are somehow dispossessed of the landscapes because of their blindness, so we can safely appropriate them. This appropriation erases the boundary between the place where the actual reader is situated when reading the book and the place to which (s)he is transported within the novel. This dis-location however is not experienced as a dislocation of the self but as a decentring. Unlike John Jr. the reader is not torn from the place in which (s)he is rooted, (s)he learns to dwell within another place. John's trajectory is characterised by a violent centrifugal movement while the reader's is a progressive centripetal movement that teaches him/her to adopt a different standpoint.

Massey deplores the fact that "there is a persistent Russian-doll geography of ethics, care and responsibility: from home, to local place, to nation. There is a hegemonic understanding that we care first for, and have our first responsibilities towards, those nearest in" (Massey 186). Although Brown's rejection of the sentimental idealisation of supportive rural communities in Kailyard novels leads him to paint a community too cruel and callous for us to sympathise with them, the novel does teach us to question this geography of affect, for it does not rely on a Russian-doll effect that would simply expand our interest from England to Britain. Instead it leads us to accept the possibility of a different centre. In "Between Geography and Philosophy," Edward Casey underlines the fact that the geographical self does not have one but "two effective epicentres": the body—through which place makes a mark on us-and the landscape without which "we would be altogether confined to the peculiarities of a particular place" (Casey 2001a, 690). By drawing the reader within the landscape, the narrator achieves that outward movement "beyond any particular place and beyond any body in that place" (Casey 2001a, 690). Instead of expanding into a bigger version of ourselves which would lead us to appropriate - and thus negate- the Other, we become aware of the coeval nature of self and other.

\section{"Pride will have a downcome": the Use of Spatial Metaphors in the Novel}

While it is easy to associate the horizontal axis with geography and location, the vertical axis that determines one's hierarchical position on the social ladder might be perceived as more abstract and less connected with the notion of place. As became apparent in the analysis of the novel's horizontal axis, however, there is a strong connection between the two axes, for the horizontal axis is about symbolic power as much as geographical reality. Conversely, in the novel, the vertical axis is linked with such abstract notions as hierarchy and hubris, yet it is also 
inscribed within the material world through the references to Scotland's specific topography, thus uniting the universal and the local. Since Scottish landscapes are marked by their relief, contrasting with the flatness of English lands, it seems natural that this visual representation of space should shape the language of Barbie's inhabitants and particularly their choice of metaphors. Geographical reality and proverbial phrases thus echo each other throughout the text when, taunting Gourlay through an allusion to Wilson's success and Gourlay's own failure, Brodie-one of the "bodies"-exclaims: "He goes up the brae as fast as some folk are going down't" (122). The irony is all the more cruel since Gourlay himself has made use of the vertical symbolism to signify his position in the town's hierarchy. It is certainly no coincidence that the House with the Green Shutters, which is meant to represent Gourlay to the world, should occupy a "commanding station" (14-15), thereby enabling him to look down on the rest of the town both literally and figuratively. This polysemous interpretation is suggested in the very first chapter when the narrator first underlines that in this summer morning Barbie is "a very pleasant place to look down at" (1) before alluding to Gourlay's pride and the fact that "to look down on the petty burgh in which he was the greatest man, filled all his being with a consciousness of importance" (2). While in the first instance the phrasal verb only refers to a spatial movement, in the second there is clearly a duality of meaning and the notions of pride, pettiness and importance with which the phrase is associated lead the reader to understand, not only that there is a shift in meaning but that the figurative sense actually predominates over the literal.

The most striking example of spatial images to describe Gourlay's hubris is perhaps the use of the verb "to down," for Gourlay never defeats or humiliates his opponents, he always "downs" them. This unusual phrase is used on no less than eleven occasions in the novel. Although two of those occasions refer to John Jr.'s mere imaginary "downing” of another character, every other occurrence is used to describe Gourlay's very real treatment of his enemies. When the narrator employs this verb, it appears between inverted commas, suggesting, in all likelihood, that he is quoting a phrase used by the inhabitants of Barbie. However, the punctuation also draws our attention to this verb, which comes to symbolise Gourlay's ascendency over every other character in the novel. Its repetition in the text becomes the linguistic equivalent of the multitude of props that Gourlay uses to assert his superiority. In addition to the house, his gig also falls into this category: he is "seated high" upon the latter, for " $[\mathrm{t}]$ hat driving cushion was Gourlay's pedestal from which he looked down on Barbie for many a day" (118). Finally, the symbolism of the vertical trope is used again in the patricide scene, with the father standing on a ladder towering above his son:

If Gourlay had been on the floor he would have grappled with him there and then. But the temptation to gloat over his victim from his present height was 
irresistible. He went up another step, and sat down on the very summit of the ladder, his feet resting on one of the lower rounds. (226)

Predictably, Gourlay's hubris is duly chastised since his son hits him with the poker as he leaps down. However, his death will not actually put an end to the father's psychological domination over the son, for the latter will be haunted by his father's eyes watching him "from aloft" (245) when he commits suicide.

In its mythological dimension, hubris represents the trespassing of natural boundaries that leads to Nemesis, which will force the trespassers to fall back within the narrower space that should have been theirs. While such trespassing can be horizontal as well as vertical, Herodotus's choice of examples to illustrate the concept of hubris clearly associates it first and foremost with verticality (Herodotus III 310). In its civic dimension, hubris refers to outrage, ${ }^{3}$ and thus causes such dishonour to the victims that they are entitled to refuse blood money and demand inflexible vengeance ( $\left.\dot{\alpha}^{v} \alpha_{1} \delta \varepsilon \dot{\varepsilon} \alpha\right)$. Gourlay is guilty of both forms of hubris. Believing himself "invulnerable," he has "trodden under foot" (207) the inhabitants of Barbie. He has also built a house in which everything has to be "grand," "without its equal in the parish" (18) and out of ordinary proportion, such as the poker-head with which his son will kill him. His social punishment takes the form of ostracization and general hatred, but he is also struck by Nemesis. Just like his superiority, his fall is prophesised and described through the use of spatial prepositions and morphemes. Although the words "failure" and "defeat" are found in the text, "downfall" and "comedown" are more frequent. This fall is announced as early as the second chapter, when Gourlay is still at the pinnacle of his triumphant success: "if the railway came hereaway I wager Gourlay would go down,' [the Provost] added, less in certainty of knowledge than as prophet of the thing desired. 'I wager he'd go down" (10). It is then confirmed and eagerly expected, being presented as a decree of fate:

'He's bound to come down,' said Certainty. (198, original emphasis)

'Pride will have a downcome,' said some, with a gleg look and a smack of the lip, trying to veil their personal malevolence in a common proverb. (199, original emphasis)

3. Aristotle defines it as follows: "he who insults another also slights him; for insult consists in causing injury or annoyance whereby the sufferer is disgraced, not to obtain any other advantage for oneself besides the performance of the act, but for one's own pleasure [...] The cause of the pleasure felt by those who insult is the idea that, in ill-treating others, they are more fully showing superiority" (Aristotle 175). In this English edition, üßpı is translated by "insult" but French translations tend to use the stronger synonym "outrage," which is also the word used in The House with the Green Shutters. In this context the word hubris often had strong sexual connotations, a dimension which the narrator also takes into account when comparing absolute humiliation with rape (211). 
The narrator's comments about the Provost's wishful prophecy and the anonymous characters' hiding their vengeful desires behind the veil of a general statement somehow debunk their attempt to present Gourlay's misfortune in the light of divine retribution. However, this is precisely what the text itself achieves, through its adoption of the tropes of Greek tragedy, and more especially the concept of Nemesis. From a diegetic point of view, it is achieved through the murder of Gourlay and the suicide of the other members of the family within the House with the Green Shutters. The house itself seems to be affected by the punitive shrinking associated with Nemesis if we compare its description in the first chapters with the final lines of the novel: while Gourlay had observed an arch of falling water from his higher position, standing at his gate, and the house had been described as being "planted firm" (14), the novel concludes on a depiction of "the House with the Green Shutters, sitting dark there and terrible, beneath the radiant arch of the dawn" (252). Using the verb "sit" instead of "stand" to refer to a house may in some other contexts suggest cosiness. Here, however, it suggests a crouching position and its position beneath the arch of light, just like the adjectives "dark" and "terrible" both suggest chthonic ${ }^{4}$ forces and imply that it has somehow fallen from its original position and occupies a more constricted space. Moreover, there is a sense of poetic justice implied in the semantic echoes of the text: he who has constantly "downed" others "goes down" and meets his death when he leaps down from a ladder.

Gourlay's hubris is not the only excessive pride that needs to be chastised, however. Just as John Jr.'s journey is mirrored by that of the reader, the downfall of his father is echoed through a questioning of the linguistic hierarchy that places Scotland geographically and linguistically on the periphery of an Anglo-centric vision of the world. "All linguistic practices are measured against the legitimate practices, i.e. the practises of those who are dominant" (Bourdieu 53), and this is illustrated in the novel through phrases that also hint at verticality when John Jr.'s anglicised style of speech is associated with a "lofty pose" (Letley 313,

4. Bachelard describes the house as a vertical being "It rises upward. It differentiates itself in terms of verticality" (Bachelard 38) and this "verticality is ensured by the polarity of cellar and attic" (38). Brown's narrator definitely seems sensitive to the poetics of the attic associated with daydreaming (Bachelard 32): "to snuggle close beneath the slates is as dear to the boy as the bard [...]. Your garret is the true kingdom of the poet, neighbouring the stars; side-windows tether him to earth, but a skylight looks to the heavens" (50). The vertical polarity might however seem at first incomplete in the novel since there is no reference to the cellar of the House with the Green Shutters but the chthonic forces are present nevertheless, embodied in the house's owner and alter ego, Gourlay, with his inhuman fearlessness and his "black glower." At the end of the novel, even the positive imagery associated with the garret is ruined by Mrs Gourlay's suggestion that her daughter's only alternative to suicide is to "hoast [herself] to death in a garret in the poorhouse" (248), a fate she actually considers as worse than death by poison. Once it has become a tomb for the whole family, it is the house itself that embodies the cellar as "buried madness, walled-in tragedy" (Bachelard 41). 
Brown 159) or when the Reverend Struthers-nicknamed "puffy importance" (162)-is described as "stooping to Scotch" (164). There is a double-edged irony in this comment for while it obviously stigmatises the minister's affectation, it also suggests that if this man is ridiculous, so is his notion-and by extension the implied reader's conviction-that Scots is a baser language.

In his assessment of the Scottish vernacular, Brown adopts the traditional vision that it is a language that should be spoken rather than written and that "a prent beuk" should only display it in dialogue while the connecting narrative prose should be in English (Letley 298). When the sons of the Barbie dignitaries go to the high school of Skeighan and to the university of Edinburgh, they are taught to use English rather than their native tongue, in order to increase their value on the job market and their symbolic power. Brown is aware of this phenomenon and endorses this ideology to a certain extent when he chooses to have a narrator whose authority and superiority over the characters of the novel is implicitly asserted by his use of the legitimate language. Indeed, as Craig stresses when he analyses the linguistic revolution operated by Kelman:

in any novel written in standard or "literary" English, a linguistic hierarchy is established in which, no matter the intent of the author, the dialect-speaking character is always the inhabitant of a linguistically less significant world than that shared by author and reader: the dialect-speaking character is seen as being either in declension from, or in aspiration towards, the moral and intellectual standards - the full humanity—of standard English and its literary traditions. (Craig 78)

Like every other writer before Kelman, Brown follows this tradition and thus confirms the reader's notion that dialects are linguistically less significant, that they are tokens of inferiority. Moreover, he is wary of the association of printed Scots with vulgar humour and maudlin pathos (Letley 298). As Letley underlines, there are actually passages in the novel in which he parodies this sentimental use of Scots: "Allan remembers John Gourlay's mother in the language of sentiment: in this case, of course, stereotypic Scots. She is still the young flicksie and the wee bit lairdie's dochter" (Letley 308).

However, Brown is also convinced that the Scottish voice "enlarges the word" and he claims that in places where Scots has not been "bastardized by the Board School [...] the patois [is] spoken with the dignity of a classical tongue" (Letley 299), thus implying that it can rank higher than English in the traditional linguistic hierarchy. This statement is never clearly illustrated in The House with the Green Shutters, although one might argue that it is hinted at through the elements of Greek tragedy transposed into a Scottish context. On the other hand, Brown's praise of the capacity of Scots to "plant a picture in the mind for every single terrible phrase" (Letley 299) is expressed explicitly when Tarmillan (one of John Jr.'s fellow students in Edinburgh) praises the vividness of speech 
of the Scottish peasantry and claims that the English people's admiration for Carlyle should actually extend to his fellow countrymen: "To hear Englishmen talk, you would think Carlyle was unique for the word that sends the picture home-they give the man the credit of his race" (140). Although Tarmillan is not to be seen as Brown's spokesman in the novel, in this particular instance their views definitely coincide, and it is worth noting that Brown uses the same anecdote in his notes to David Meldrum and his novel:

'I'll gar your brains jaup red to the heavens,' said one to another in a quarrel, and a nervous bystander looked up to the far fleecy clouds in the peaceful blue to see if they were yet bedabbled by the spouting gore. (Veitch, qtd Letley 299)

"I can cap that with a better one still," said Tarmillan, who wasn't to be done by any man. "I was with Bauldy when he quarrelled Tam Gibb of Hoochandoe. Hoochan-doe's a yelling ass, and he threatened Bauldy-oh, he would do this, and he would do that, and he would do the other thing. 'Damn ye, would ye threaten me?' cried Bauldy. 'I'll gar your brains jaup red to the heavens!' And I 'clare to God, sirs, a nervous man looked up to see if the clouds werena spattered with the gore!" (140-41)

Moreover, the characters of the novel repeatedly make fun of those who fetishize the legitimate language and "thpeak fancy English" (9), and although their opinion is not to be regarded as authoritative, it does introduce an element of rebellion against the hegemonic view of linguistic hierarchy.

As was noted earlier, the narrator's position towards his place of origin is ambiguous and so is his positioning towards language. When he contextualises Scottish words or glosses them in a footnote, he draws attention to their exoticism and therefore consigns them to the periphery of language. However, the boundary between English and Scots is sometimes blurred, either through the use of free indirect speech-which reduces the distance between the narrator's voice and the characters' - or when the narrator himself uses Scottish words or a spelling that echoes Scottish pronunciation without introducing distancing devices such as quotation marks or footnotes. Thus, to quote only a few examples, one of the secondary characters, William Wilson, becomes Weelyum (67)—as his cousin calls him-even in the narrative passages, we are also told that Mrs Wilson's laugh "went skelloching up the street" (97) and there are numerous references to Gourlay's "birr." As Craig underlines in his introduction to the novel, Brown also introduces Scotticisms which may be hardly perceptible for the reader: "'Ill to disturb' is one of the many phrases that have no specific Scottish words in them, but which represent a way of speaking and writing English which is quite distinctly Scottish" (xii). This is a perfect example of what Stevenson describes in "The Foreigner at Home" when he claims that "even though his tongue acquire the Southern knack, [the Scot] will still have a strong Scotch 
accent of the mind" (Stevenson 23). This accent of the mind, the creativity and "the expansiveness of [the novel's] language" (xiii) are the best counter-hegemonic discourse that the text could produce to counteract prejudices against Scots.

The House with the Green Shutters is both inscribed in the localthrough landscapes, vernacular language and the identification of a specific Scottish habitus-and the universal-through its description of humanity's desire for emplacement, for stabilitas loci. The permanence of place is an illusion for place is "open-textured, ever altering, always challenging, never fixed" (Casey 2001b, 719) and yet it has inscriptive tenacity. Indeed, if our experience of a place has been intense, "we are forever marked by that place, which lingers in us indefinitely and in a thousand ways, many too subtle for us to name. The inscription is not of edges or outlines, as if place were some kind of object; it is the whole brute presence of the place. What lingers most powerfully is this presence and, more particularly, how it felt to be in this presence" (Casey 2001a, 688 , original emphasis). The House with the Green Shutters illustrates this tenacity of place in the description of its characters' attachment to their home but it also demonstrates the capacity of language to create places that leave a tenacious trace in the reader's mind. Brown had clearly been marked by his childhood experience in Ochiltree (Ayrshire), so much so that he could picture that place vividly even when he was writing about it from London. He, in turn, left his mark on the place and shaped our vision of Scotland. The house in which he was born now bears a memorial plaque and Ochiltree is forever associated with Barbie. Even more importantly, Brown's novel has imprinted its mark on the Scottish literary landscape. Books create geographies of their own and writers travel through these places, building bridges between them, using them as landmarks to guide the reader through the literary maps of their own works. In Sunset Song, Lewis Grassic Gibbon playfully inscribes both Kailyard and anti-Kailyard works in his own novel and implies that literature has the power to "father" the very essence of the Scottish landscape. The comment on his character's allusion to The House with the Green Shutters suggests that its evocative power is such that it haunts the Scottish landscape and psyche even in its absence:

So there was Kinraddie in the bleak winter of nineteen eleven and the new minister [...] was to say it was the Scots countryside itself, fathered between a kailyard and a bonny brier bush, in the lee of a house with the green shutters. And what he meant by that you could guess at yourself if you'd a mind for puzzles and dirt, there wasn't a house with green shutters in the whole of Kinraddie. (Gibbon 24) 


\section{Bibliography}

Aristotle. Art of Rhetoric. Trans. J.H. Freese, Loeb Classical Library, n 193. Cambridge, MA: Harvard UP, 1926.

Bachelard, Gaston. The Poetics of Space. 1957. Trans. Maria Jolas, 1964. New York: Penguin, 2014.

Bourdieu, Pierre. Language and Symbolic Power. Trans. Gino Raymond and Matthew Adamson. Cambridge: Polity Press, 1991.

Brown, George Douglas. The House with the Green Shutters. [1901] Ed. \& intro. Cairns Craig, Edinburgh: Canongate, 1999.

Bruce, George and Paul H. Scott. A Scottish Postbag. Eight Centuries of Scottish Letters. 1986. Saltire Society. Edinburgh: Chambers, 2002.

Campbell, Ian. "George Douglas Brown's Kailyard Novel." Studies in Scottish Literature 12.1 (1974): 62-73.

Campbell Ian and Vogel, Brian. "The House with the Green Shutters and the Seeing Eye.” Studies in Scottish Literature 27.1 (1992): 89-104.

Carruthers, Gerard. Scottish Literature. Edinburgh: Edinburgh UP, 2009.

Casey, Edward. Getting Back Into Place : Toward a Renewed Understanding of the Place-world. Bloomington: Indiana UP, 1993.

- . "Between Geography and Philosophy: What Does It Mean to Be in the PlaceWorld?" Annals of the Association of American Geographers 91.4 (Dec. 2001a): 683-93.

—. "On Habitus and Place: Responding to My Critics." Annals of the Association of American Geographers 91.4 (Dec. 2001b): 716-23.

Civardi, Christian. "The House with the Green Shutters: a Chapter of the Moral History of Scotland.” RANAM 5 (1972): 194-206.

Craig, Cairns. The Modern Scottish Novel: Narrative and the National Imagination. Edinburgh: Edinburgh UP, 1999.

Decap, Roger. George Douglas Brown et le roman dramatique. Toulouse: Éditions Universitaires du Sud, 2003.

De Certeau, Michel. The Practice of Everyday Life. Trans. Steven Randall, 1984. Berkeley and Los Angeles: U of California P, 1988.

Gibbon, Lewis Grassic. Sunset Song. 1932. Edinburgh: Canongate, 1988.

Gifford, Douglas. "Myth, Parody and Dissociation: Scottish Fiction 1814-1914." The History of Scottish Literature Vol. III, Nineteenth-Century. Ed. Douglas Gifford. Aberdeen: Aberdeen UP, 1988. 217-261.

Gifford, Douglas and Gibson, Gordon. "George Douglas Brown: The House with the Green Shutters." Scottish Literature. Eds. Gifford, Douglas, Dunningham Sarah and Alan MacGillivray. Edinburgh: Edinburgh UP, 2002. 447-460.

Herodotus. The Persian Wars. Trans. A. D. Godley, 4 vols, Loeb Classical Library, $\mathrm{n}^{\circ}$ 117-20. Cambridge, MA: Harvard UP, 1920.

Hill, Jen. White Horizon: the Arctic in the Nineteenth-Century British Imagination. New York: U of New York P, 2009.

Letley, Emma. From Galt to Douglas Brown. Nineteenth Century Fiction and Scots Language. Edinburgh: Scottish Academic Press, 1988.

Macdonald, Angus. “Modern Scots Novelists.” Edinburgh Essays on Scots Literature. Ed. H. Harvey Wood. Edinburgh; London: Oliver and Boyd, 1933. 149-73.

Massey, Doreen. For Space. London: Sage Publications, 2005.

Nash, Andrew. "The Kailyard: Problem or Illusion." The Edinburgh History of Scottish Literature. Volume Two: Enlightenment, Britain and Empire. Eds. Ian Brown, Thomas Clancy, Susan Manning and Murray Pittock. Edinburgh: Edinburgh UP, 2006. 325-32. 
Royle, Nicholas. "The Ghost of Hamlet in The House with the Green Shutters." Studies in Scottish Literature 27.1 (1992): 105-12.

Scott, John Dick. "R.L. Stevenson and G.D. Brown.” Horizon 13 (1946): 298-310.

Sellin, Bernard. "George Douglas Brown's The House with the Green Shutters: a sense of place." Literatur im Kontext. Eds. Joachim Schwend, Susanne Hagemann, Hermann Völkel. Frankfurt am Main: Peter Lang, 1992. 173-182.

-. "Poétique de la maison dans The House with the Green Shutters." Études écossaises 2 (1993) : 187-194.

Sommers, Jeffrey. "Notes and Documents: George Douglas Brown and Thomas Hardy." Studies in Scottish Literature 19.1 (1984): 252-58.

Stevenson, Robert Louis. "The Foreigner at Home." Memories and Portraits. New York: C. Scribners and Sons, 1910. 3-23.

Veitch, James. George Douglas Brown. London: Herbert Jenkins, 1952. 